Fall 1995

\title{
Information Technology and Legal Ethics: Expanding the Teaching and Understanding of Legal Ethics through the Creation of a New Generation of Electronic Reference Materials
}

\author{
Roger C. Cramton \\ Cornell Law School, rcc10@cornell.edu \\ Peter W. Martin \\ Cornell Law School, peter.martin@cornell.edu
}

Follow this and additional works at: http://scholarship.law.cornell.edu/facpub

Part of the Ethics and Professional Responsibility Commons, and the Legal Education Commons

\section{Recommended Citation}

Cramton, Roger C. and Martin, Peter W., "Information Technology and Legal Ethics: Expanding the Teaching and Understanding of Legal Ethics through the Creation of a New Generation of Electronic Reference Materials" (1995). Cornell Law Faculty Publications. Paper 1216.

http://scholarship.law.cornell.edu/facpub/1216 


\title{
INFORMATION TECHNOLOGY AND \\ LEGAL ETHICS: EXPANDING THE TEACHING AND UNDERSTANDING OF LEGAL ETHICS THROUGH THE CREATION OF A NEW GENERATION OF ELECTRONIC REFERENCE MATERIALS
}

\author{
Roger C. Cramton* and Peter W. MARTin ${ }^{* *}$
}

\section{INTRODUCTION}

The law and ethics of lawyering is as vital a subject as any in the law curriculum-perhaps the most vital. Yet in many law schools it is relegated to a one-credit or two-credit required course in the upperclass years, often taught by adjuncts. ${ }^{1}$ In a minority of law schools, including some of the most prestigious, a course dealing explicitly with what lawyers do, how the profession is structured and regulated, and what legal and ethical norms govern lawyer conduct is not required. ${ }^{2}$ These schools state that instruction in these topics

Copyright $\odot 1996$ by Law and Contemporary Problems

* Robert S. Stevens Professor of Law, Cornell Law School; director, Cornell Law School Legal Ethics Program, which is funded in part by a grant from the W.M. Keck Foundation.

** Jane M.G. Foster Professor of Law, Cornell Law School; co-director, Cornell Legal Information Institute.

1. The extensive involvement of lawyers in the Watergate coverup led to public and professional concern that legal ethics be taught in law school. Shortly afterward, a survey indicated that every ABA. approved law school offered instruction in professional ethics and most of them made it mandatory. See Stuart C. Goldberg, 1977 National Survey on Current Methods of Teaching Professional Responsibility in American Law Schools, in 1977 NATIONAL CONFERENCE ON TEACHING PROFESSIONAL RESPONSIBILITY vii, ix \& xvi (Stuart C. Goldberg ed., 1977). A 1991 survey revealed that 91 of 92 responding schools had a mandatory course, although the majority of them were for two credits or less. NEwSLETTER OF AALS SECTION ON PROFESSIONAL RESPONSIBILITY (AALS, Fall 1991). Today a large number of schools require a three-credit legal ethics course.

2. As of academic year 1995-96, a number of major law schools required little or no instruction in legal ethics: Boston University School of Law (no required course; a two-day introduction, receiving no academic credit and ungraded, is required during the January intersession of the first year); University of Chicago Law School (a 1.5 credit course is required prior to graduation); Columbia University School of Law (a five-day intensive course, receiving one credit and graded on a pass-fail basis, is required at the beginning of the third year); Duke University School of Law (a five-day intensive course, receiving one credit and graded on the same basis as other courses, is required during the January intersession of the first year); University of Michigan Law School (exposure to legal ethics either by taking an elective two-credit or three-credit course in the subject, or, in the current year, by a five-day, one-credit "bridge week" involving all first-year classes and graded on a pass-fail basis); Stanford Law School (no required course; first-year faculty are encouraged to include a module on legal ethics in their courses); and Yale Law School (once-a-week lectures or presentations are required during 
"pervades" the curriculum but, when questioned, concede that most of their teachers neither feel comfortable dealing with legal ethics nor devote substantial time in their courses to it. ${ }^{3}$ The pervasive method by itself is usually a pretense rather than a reality. To be effective, it must be supplemented by a required course in the subject and by faculty agreement, supported by monitoring, to include ethics modules in required and heavily elected law school courses.

What would be the elements of an ideal law curriculum that recognized that the law and ethics of lawyering (and associated issues concerning access to legal services and the behavior and regulation of the legal profession) are as important to legal education as core subjects such as civil procedure, contracts, torts, and property? Our answer is clear. First, the subject would be a significant part of the required curriculum of the formative first year of law school. ${ }^{4}$ Second, if the first-year treatment were less than a three-credit course, an upperclass requirement of at least that dimension would provide systematic treatment of the subject. Third, the basic concepts of the subject-such as confidentiality, avoidance of conflicting interests, and the significance of the lawyer's distinct roles as a counselor (the private ordering carried on in the law office) and as an advocate (the lawyer's partisan and combative role in contentious public proceedings)-would be explored and replicated in the practice contexts that form the implicit but specific backdrop of most widely elected courses, such as corporate practice, criminal prosecution or defense, matrimonial dissolution, and estate planning. In short, the law and ethics of lawyering would pervade the curriculum, just as the core issues of first-year civil procedure or contracts are revisited in richer detail in upperclass courses that deal with procedural topics (such as Administrative Law, Evidence, Advanced Civil Procedure, Federal Courts, Conflict of Laws, and Trial Practice) or contractual relations (such as Commercial Law, Debtor-Creditor, Insurance, and various transactional courses). Fourth, because students learn in different ways and at different times, a variety of teaching methods would be used in this succession of courses, some employing a rigorous dialectical approach, others involving other approaches such as humanistic inquiry or clinical methods. This array of elective offerings also would offer more specific treatment of individual

the first term of law school on a non-credit, ungraded basis). Note that none of the seven schools require that each J.D. student take at least two semester hours of instruction in legal ethics.

3. For a discussion of the possibilities and limitations of the "pervasive" approach, see Deborah L. Rhode, Ethics by the Pervasive Method, 42 J. LEGAL EDUC. 31, 50-56 (1992).

4. Two possibilities are discussed in the papers published in this symposium. The first is a required first-year course devoted to professional ethics. See Stephen M. Bundy, Ethics Education in the First Year: An Experiment, 58 LAW \& CONTEMP.PROBS. 19 (Summer/Autumn 1995). The second is a first-year introduction such as at Duke (one-week intersession course) and Michigan ("bridge week" involving several first-year sections). See Thomas B. Metzloff, Seeing the Trees Within the Forest: Contextualized Ethics Courses as a Strategy for Teaching Legal Ethics, 58 LAW \& CONTEMP.PROBS. 227 (Summer/Autumn 1995) (Duke); Heidi Li Feldman, Enriching the Ethics Curriculum: From Requirement to Desire, 58 LAW \& CONTEMP.PROBS. 51 (Summer/Autumn 1995) (Michigan); Edmund B. Spaeth, Jr., et al., Teaching Legal Ethics: Exploring the Continuum, 58 LAW \& CONTEMP.PROBS. 15456 (Summer/Autumn 1995) (describing Penn's two-week first-year course taught prior to 1992). 
practice contexts to smaller groups of students (such as ethics in tax practice) and interdisciplinary seminars connecting lawyers and the legal profession to some related body of information or ideas (such as history or sociology of the legal profession, lawyering and moral philosophy, economic analysis of legal institutions). Finally, most of these subjects, and especially the required courses, would be taught primarily by tenured and tenure-track members of the faculty who have a serious scholarly interest in the law and ethics of lawyering.

The painful reality is that not a single law school in the United States combines in its current faculty and curriculum the elements mentioned above. Professional ethics receives prominent attention in deans' speeches or law alumni publications, but gets a whisper and a promise when it comes to selection of law faculty, inclusion in the core curriculum, and pursuit of faculty research interests. Perhaps the underlying purpose of the W.M. Keck Foundation's recent grant program in the field of legal ethics is an attempt to remedy this neglect in the law schools and, through broadened understanding by law graduates, heighten ethical awareness in the practicing profession.

Cornell Law School's use of the Keck grant takes a series of steps toward this ideal curriculum. The grant program is designed to expand and improve the teaching of legal ethics at the law school by a combination of means: first, add to the challenge, interest, and depth of the current required three-credit course on the law and ethics of lawyering; second, expand and improve the teaching of legal ethics throughout the law curriculum by encouraging faculty members to introduce legal ethics in first-year and upperclass courses that are part of the law school's "core curriculum"- that identifiable group of subjects that are either required or highly elected; and, third, utilize new technology to build and disseminate a rich collection of legal ethics materials.

The first two elements are largely inward-looking, designed to improve our efforts at Cornell, but they reach out by providing a format or content that will enable law teachers elsewhere to achieve the same objectives. The third element is primarily outward-directed: the creation of a major new information resource available either free of charge or at low cost to law students, law teachers, lawyers, courts, and the general public. Indeed, this material will be available to anyone anywhere who can access the Internet.

Part II of this essay presents a very brief summary of the inward-looking elements of the Cornell program, which parallel efforts at a number of other law schools to improve the basic required course in professional ethics and to encourage the pervasive teaching of the subject throughout the law curriculum. Because efforts of this kind, including their advantages and drawbacks, are discussed in a number of other papers in this symposium, ${ }^{5}$ we shall focus in Part

5. See especially Bundy, supra note 4; Robert P. Burns, Teaching the Basic Ethics Class Through Simulation: The Northwestern Program in Advocacy and Professionalism, 58 LAW \& CONTEMP. PROBS. 37 (Summer/Autumn 1995); Susan P. Koniak \& Geoffrey C. Hazard, Jr., Paying Attention to the Signs, 58 LAw \& CONTEMP. Probs. 117 (Summer/Autumn 1995); Carrie Menkel-Meadow \& Richard H. Sander, The "Infusion" Method at UCLA: Teaching Legal Ethics Pervasively, 58 LAW \& CONTEMP. 
III on the unique aspect of the Cornell program: the preparation and dissemination of electronic material on legal ethics on a state-by-state basis. This material can provide law teachers and practitioners with a comprehensive resource adaptable to their individual needs. Most of this essay and the computer disk (CD-ROM) that is inserted in an envelope inside the rear cover of this issue of Law and Contemporary Problems provide information concerning this technological innovation. For additional information, the reader may examine the current, and probably much expanded, legal ethics library through the Cornell Legal Information Institute's Internet address or by communicating with the Institute by phone, fax, or e-mail. ${ }^{6}$

II

IMPROVING THE BASIC COURSE AND PERVASIVE INSTRUCTION

\section{A. Case Studies}

Cornell uses its grant from the W.M. Keck Foundation to expand and improve the teaching of legal ethics throughout the law curriculum by bringing into a large number of required or highly elected courses structured discussions with experienced and thoughtful practitioners about pervasive legal ethics problems. During fall term 1995, for example, civil procedure teachers cooperated with legal ethics teachers in two-hour programs on discovery abuse: they discussed a rich case study with civil litigators who struggle daily with the question of interpreting and responding to discovery requests.

We use the term "case study" to describe an actual or hypothetical situation that presents important issues of professional ethics in a practice setting that is relevant to the law school course for which it is designed. The case is then supported by text, rules, and excerpts that provide what the regular course materials do not-a thorough treatment of the law and ethics of lawyering relevant to the case. The students are placed in the lawyer's position of considering the alternative courses of action available, which forces an evaluation of the consequences of the possible paths. In their initial use, the problems are being presented with the assistance of distinguished practitioners with expertise in both the substantive and ethical aspects of the case study. These lively interactions of students and practitioners provide the basis for a series of further developments: improvement of the problem; generation of a teacher's guide for the problem's future use; enhancement of the instructor's capacity and

PROBS. 129 (Summer/Autumn 1995); Deborah L. Rhode, Into the Valley of Ethics: Professional Responsibility and Educational Reform, 58 LAW \& CONTEMP. PROBS. 139 (Summer/Autumn 1995); David B. Wilkins, Redefining the "Professional" in Professional Ethics: An Interdisciplinary Approach to Teaching Professionalism, 58 LAW \& CONTEMP. PROBS. 241 (Summer/Autumn 1995).

6. The Internet address is http://www2.law.cornell.edu/folio.pgi/RPC-OVERVIEW?. The phone number is (607) $255-6536$, and the fax number is (607) $255-7193$. 
willingness to teach the problem in the future without outside assistance; and, finally, dissemination of the case study for use elsewhere.

Two other case studies were developed and considered for use in the fall of 1995. One exposed the large class in Trusts and Estates to an intensive discussion of the legal and moral issues of loyalty, confidentiality, and conflict of interest in joint representation of a husband and wife in estate planning. A second case study, which was used in the core course in corporations, dealt with the problems faced by a lawyer representing a corporation when the lawyer suspects, then learns, that the persons in control are engaged in an illegal course of conduct. All three case studies were also used in a one-hour class session of the required Professional Ethics course, with the outside practitioners adding energy, credibility, and interest to the basic course.

Six additional case studies were prepared by Professor Roger C. Cramton for use during academic year 1995-96; others are in preparation for use in future years. Teachers in the particular subject matter cooperate in the preparation of the case studies and the manner of their use. It is hoped that a library of such materials will be available, perhaps growing at the rate of six case studies annually, through either a commercial publisher or on a free basis via Internet and computer disk.

The case studies are intended to encourage and enable teachers of courses throughout the law curriculum to include a sophisticated legal ethics component in their courses and to supplement and improve the teaching of professional ethics, which now is confined generally to a required upperclass course. The need for this approach rests on several well-founded assumptions. First, most casebooks include very little material on important ethics issues that frequently arise in the areas of practice dealt with in the course, such as estate planning (Trusts \& Estates) or corporate representation (Corporations). Second, many law teachers are unfamiliar with much of the case law, ethics rules, ethics opinions, and academic commentary dealing with issues of the law and ethics of lawyering. Because legal academics feel a compulsion to have near total control of every issue undertaken in core courses, this unfamiliarity leads them to avoid explicit treatment of ethical issues. Nevertheless, lessons of lawyer role and conduct are taught implicitly, indirectly and often badly, even though not explicitly. Finally, because law practice is highly contextual in nature, generalizations about lawyer behavior invariably fail to reflect the circumstances, conditions, and substantive rules of a particular area of practice. Exposing students to these variations throughout the curriculum is a good way to heighten their ethical sensitivity.

\section{B. Visitors From Practice and Colloquia}

A related aspect of the Cornell Keck project involves the use of practitioners to teach advanced courses and workshops that relate ethics issues to an area of practice (such as ethics issues in tax practice) and the mounting of larger scale colloquia involving scholars, judges, and lawyers in discussion of cutting-edge 
problems that also involve serious legal ethics issues. The first colloquium, dealing with tort, procedural, and ethics issues in mass tort settlement class actions, is available in published form in a special issue of the Cornell Law Review. $^{7}$

In summary, Cornell's inward-looking activities are designed to improve the teaching of professional responsibility along several dimensions: (1) supplement the interest and intellectual challenge of the required professional responsibility course; (2) encourage faculty members who teach the bulk of the law curriculum to develop a significant ethics perspective in those courses; (3) excite student interest in legal ethics, and heighten their ethical sensitivity, by demonstrating the contextual and practical significance of the legal and moral aspects of lawyering; and (4) develop materials that can be easily and effectively used by law teachers in basic courses throughout the United States.

\section{III}

\section{TAKING Advantage of New Technology To BuILd AND Disseminate A RICH COLlECTION OF LEGAL ETHICS MATERIALS}

Cornell has undertaken an effort to develop an interactive, on-line resource available to the general public. For the past three years, the Legal Information Institute of Cornell Law School ("LII") has published electronic editions on diskette of core materials for important law school courses. ${ }^{8}$ These publications are not simple word processor files, but are high-end works comparable to, indeed surpassing, in both functionality and quality of editorial enhancement, the commercial CD-ROM publications now available to lawyers. Early examples of such LII materials include the Administrative Procedure Act of the United States, the Federal Rules of Civil Procedure, and the Uniform Commercial Code.

These materials offer a more powerful alternative to the standard print supplements ("Selected Statutes on ...") commonly used in law school courses requiring use of one of the mentioned codes. The LII's disk-based materials are designed for installation on a local area network or public workstations in a library, for loading on individual student or faculty machines, or both. The Folio VIP software bundled with these publications allows student and faculty users to move through core statutes or codes-entering at any point, following cross-references, checking definitions, moving to official comments (and back) - all by means of a simple hypertext "point and click." The software also enables full text search. Beyond these "navigation" possibilities, which no print supplement can offer, the software allows print-on-demand and extraction in the

7. Symposium, Mass Tortes: Serving Up Just Desserts, 80 CORNELl L. REV. 811 (1995).

8. For background on the Institute, see Thomas R. Bruce and Peter W. Martin, The Legal Information Institute: What Is It and Why Is It?, 20 CORNELL L. FORUM 3 (1994). For greater detail on the LII's current activities, visit its Internet site (http://www.law.comell.edu). See also Peter W. Martin, Educating Law Students in the Use of Information Systems by Using Information Systems in the Education of Law Students, ALITA, Nov. 1992, at 2. 
form of text files. More significantly, it permits users to add marginal comments, highlight text, and create their own hypertext links. As a consequence, the navigation tools are not simply pre-packaged but are available to students and faculty members, enabling more active forms of appropriation and annotation than are possible with print or on-line databases. Indeed, the open architecture of Folio VIP encourages students and faculty to add and link additional notes and documents to the "published" core text, ranging from the course outline and daily notes to downloaded cases.

In combination with its novel disk publication program, LII established the first Internet site focused on law. At http://www.law.cornell.edw/, large numbers of lawyers, law students, public officials, educators, and lay people have, since 1992, found free access to decisions of the Supreme Court of the United States, the full text of the U.S. Code, a large collection of treaties, and a growing "library" of commentary. These Internet offerings have included but not been limited to the materials the LII has published for law school (and lawyer) use on diskette.

Building on this experience and audience, Cornell's Keck projects include a major initiative focused on the key legal materials on the law of lawyering. The LII diskette offerings for academic year 1995-96 include a core collection in this field made possible by Keck support, a nucleus that will grow in several directions. This material is now available on the Internet at http://www2.law.cornell.edu/folio.pgi/RPC-OVERVIEW?.

The initial collection includes the rules of professional conduct governing lawyers in California, District of Columbia, Idaho, New York, and Texas, as well as the ABA Model Rules of Professional Conduct. All are connected by hypertext links to a topical outline of the law of lawyering. The "law of lawyering," of course, is much broader than the issues normally dealt with in state ethics codes, since it includes the law regulating the legal profession and the "other law" of agency, civil procedure, criminal law and procedure, constitutional law, and evidence to which the ethics codes either refer or are subject.9 The topical outline allows a user to begin with an issue and compare, for example, how it is treated in New York and California. The outline also has been set up so that a user focusing on a particular jurisdiction (or the Model Rules) can at any point see how the same matter is treated elsewhere. A personal notes file, based on the same topical structure, allows any user, whether faculty, student, or lawyer, to add commentary and hypertext links to any portion of the collection.

9. "Other law" refers to the generally applicable law that has special bearing on services lawyers perform for clients. For example, agents owe fiduciary duties to their principals (the lawyer-client relationship is a special form of agency); tort law provides the source of legal malpractice claims and defenses; evidence law governs the scope and application of the attorney-client privilege; the law of criminal complicity applies to lawyers who assist illegal client conduct; and constitutional law governs such matters as ineffective assistance of counsel. 
Moving a step beyond this richly linked structure of primary material with its many possibilities for comparative analysis, Professor Cramton has prepared an analytic overview of legal ethics in California that has been converted to hypertext by the LII. Its many citations of statutory and code provisions have been turned into "point and click" pathways to the underlying source.

Both Internet and disk versions of this growing body of legal ethics material have been built with an open and extensible architecture in anticipation that other jurisdictions will be added to the primary law collection and that the analytic overview for California will provide a model that can be adapted and used by experts on professional responsibility in other states.

This work is now mature enough to be used (and built upon) in law schools and by lawyers located in the jurisdictions covered in the present collection. The distribution network of Internet publication via the World Wide Web allows law schools anywhere in the United States, indeed anywhere in the world, not only to use but also to add to this core collection.

A CD-ROM containing the full set of legal ethics materials as of October 1995 , along with the software necessary to work with them, was distributed and demonstrated at the November 1-4, 1995, conference of Keck grantees at Duke University Law School. Our presentation, summarized below, concentrated on important ways this new technology can add to the effectiveness of faculty and student work on issues of legal ethics and to the connection between that work and the profession. We also pointed out specific ways that the structure we have begun can be extended and enriched by others.

Consider, for example, the following possible use of the legal ethics library. Suppose a California lawyer is interested in researching the question of whether a law firm that had provided bond counsel services to a corporation in the recent past could later represent a supplier of the corporation in major contract litigation against the former client. This lawyer could begin at any number of points in the "library"-for example, with the "dynamic table of contents" of the analytic overview of legal ethics in California or the comprehensive topical overview. Moving through either table of contents from larger to smaller topics, the lawyer would find the section dealing with "representation contrary to interest of former client." Clicking on the heading leads directly to the overview text on that subject, which in turn leads either to links to California statutes, rules, and cases or to primary materials of several states. In either case, all references to the ethics rule or relevant case law are highlighted and can be clicked on for direct access to the cited point in the full text of the underlying documents.

Alternatively, the lawyer could find the relevant text or rule by conducting a Boolean search of the textual narrative, which locates all places where "former client" is found in the text, perhaps in combination with another term. The textual narrative attached to the topic cites and links to the relevant California ethics rule and California cases and ethics opinions applying and interpreting it. Ninth Circuit decisions involving California lawyers would also be included. 
When the materials are fully developed in several years, they will include the full text of relevant case law (state and federal), ABA and state ethics opinions, and perhaps some other secondary materials. A Boolean search of the entire information base, as in a Westlaw or Lexis search, would provide an alternative way to get a listing and individual view of relevant materials. The lawyer could then gain further insight by examining ABA or ALI materials, relevant federal court decisions, or other items. The investigation might alert the lawyer to other possible issues presented by the factual situation (such as disqualification in a proceeding as a remedy for an impermissible conflict of interest or civil liability of the law firm for use of confidential information against a former client). These issues could be explored under the separate topics dealing specifically with them.

We hope that by late 1997 the legal information library will include material on at least the dozen jurisdictions that contain more than two-thirds of the nation's lawyers (listed in order of lawyer population): California, New York, Illinois, Texas, the District of Columbia, Florida, Ohio, Pennsylvania, Massachusetts, New Jersey, Michigan, and Georgia. Other large states would be added as feasible. Ultimately, the library may include the ethics laws of all U.S. jurisdictions.

Creation of the state narratives will be a major undertaking. The current plan is to employ the pro bono efforts of major law firms centered in the various jurisdictions. Every major law firm has an ethics specialist or ethics committee. These specialists and/or committees could supervise and monitor the efforts of the firms' able associates and summer law clerks. The law firm would also be in a good position to provide annual updates to keep the material current. The law firm would benefit by having its name associated with the summary of the state's law of lawyering.

Our role in the preparation of these libraries will be that of a general editor, with individual law firms as the authors for each jurisdiction. Preparation of the libraries will be eased by the following: (1) the topical organization of the textual narrative will be uniform across jurisdictions; (2) substantial portions of the narrative will be carried over to other states (the introductory statement of the topic, the issues raised, the policies involved, and a summary of the general domestic law on the subject, including summaries of ABA ethics rules, opinions, and standards as well as federal materials applicable in all states); (3) some of the primary materials will be common to all libraries (ABA materials, excerpts from the ALI Restatement of the Law Governing Lawyers, relevant U.S. Supreme Court and federal agency material); and (4) the Cornell participants (Roger C. Cramton, Charles W. Wolfram, Peter W. Martin, and Thomas Bruce, assisted by student research assistants) will provide advice, assistance, and quality control.

Thus far, these plans have been executed according to schedule. During the 1995-96 academic year, the scope and content of the legal ethics library will be enormously expanded by the addition of state-by-state textual narratives on the 
law of lawyering of the six jurisdictions containing the largest number of lawyers: California, New York, Illinois, Texas, District of Columbia, and Florida. The topical outline has been expanded and seven large national law firms, each with its home office in a major jurisdiction, have agreed to cooperate in a pro bono summer project to prepare legal ethics narratives on a state-by-state basis to supplement the ethics codes of the same jurisdictions. If all goes as planned, sometime in the fall of 1996 the Internet and CD-ROM versions of the library will include both the ethics codes and an extensive explanatory text on the law governing lawyers of California, District of Columbia, Florida, Illinois, New York, Pennsylvania, and Texas. In the following year, similar textual narratives will be added for six to eight additional states. At that point, a resource will be available that permits research in and comparison of the law governing lawyers of the jurisdictions containing a large portion of the nation's lawyers.

Cold print and oral statement are unsatisfactory means of discovering the flexibility, power, and utility of this new information technology. The reader is urged to $\log$ onto the Internet version of the library or to boot up the CD-ROM disk distributed with this publication. Seeing is one thing. Hearing adds another level of understanding. But, as the old proverb says, experiencing provides the fullest dimension. 